\title{
Comparative Study on the Effect of Three Disinfection Procedure on the Streptococcus pyogenes Biofilm Formed on Plastic Materials Used in Paedodontics and Orthodontics
}

\author{
ALEXANDRU SIMION OGODESCU ${ }^{1}$, ALEXANDRU ATTILA MORVAY ${ }^{2}$, ADRIANA BALAN ${ }^{3 *}$, LAURA GAVRILA $^{3 *}$, ANA PETCU ${ }^{3}$, \\ CARMEN SAVIN ${ }^{3}$ \\ ${ }^{1}$ Victor Babes University of Medicine and Pharmacy, Faculty of Dental Medicine, $2^{\text {nd }}$ Department, Discipline of Paedodontics, 9 \\ Revolutiei 1989 Blvd., 300070, Timisoara, Romania \\ ${ }^{2}$ National Institute of Research - Development in the Pathology Domain and Biomedical Sciences Victor Babes, 99-101 Splaiul \\ Independenei, 050095, Bucharest, Romania \\ ${ }^{3}$ Grigore T. Popa University of Medicine and Pharmacy, Faculty of Dental Medicine, 16 Universitatii Str., 700115, Iasi, Romania
}

\begin{abstract}
Plastic materials are widely used today in Paedodontics and Orthodontics for manufacturing preventive and therapeutic devices. Since these are worn for long times in the oral cavity biofilm forms on the smooth acrylic surfaces of those appliances. The biofilm must be removed not to destroy the oral microbiology. The aim of this study was to research the possibility of removing the microbial biofilm and disinfecting retainers using the photodynamic effect of toluidine blue O, Fotosan System (CMS Dental, Copenhagen, Denmark) in comparison to two products available on the market Corega Denture Cleanser Tablets (GlaxoSmithKline) and the Retainer Brite ${ }^{\circledast}$ Cleaning Tablets (DENTSPLY International Raintree Essix, FL, USA). The plastic material used in this experiment was the cold-cure acrylic Palapress ${ }^{\circledR}$ vario (Heraeus-Kulzer GmbH, Hanau, Germany). Images of the biofilm formed by Streptococcus pyogenes were obtained using a confocal laser scanning $m$ icroscope. The images were analyzed using Comstat 2 software. The results showed that all the three investigated methods had a disinfectant effect. Corega Denture Cleanser Tablets reduced most of the biofilm formed on the plastic substrate.
\end{abstract}

Keywords: acrylic resins, biofilms, disinfection, removable orthodontic appliances

In paedodontics and orthodontics acrylic resins are widely used in manufacturing of space maintainers, interceptive devices and orthodontic appliances.

The development of resins represented a great step forward in dental technique, the first thermopolymerisable acrylic resins being developed in 1936 [1].

All these acrylic resin devices should be worn by the patients many hours daily. Some can be removed daily from the oral cavity but other only after a period of time.

Bacteria can survive in nature through sporulation and adherence to both living and inanimate surfaces. The adherence to different type of surfaces leads to biofilm formation. Biofilms are involved in approximately $80 \%$ of all infections. The environment created by the microorganisms in the biofilm has a protective capacity which can confer an up to 1000 fold resistance to detergents, antiseptics and antibiotics, in comparison to freely-floating bacteria [2].

When using removable appliances, there is an excessive formation of a biofilm layer that is observed on the retentive areas of hooks and springs, and on the smooth acrylic surfaces of the appliance [3].

Studies showed that Lactobacillus and Streptococcus mutans levels are increased inside dental biofilm as a result of changing oral micro flora during orthodontic therapy with active removable appliances. Toothbrushes were not efficient enough to remove the microorganisms on the retentive areas of the appliances. Hence, it is recommended to use antimicrobial agents to eliminate the bacterial biofilm. Disinfection methods of acrylic orthodontic appliances should inactivate pathogenic microorganisms immediately, without damaging the composition of the appliance. Soaking the appliance in a chemical solution could cause decomposition of the acrylic resin molecules [4-8].

A contaminated acrylic space maintainer can induce local infections (oral mucosa stomatitis) as well as systemically ones (of upper airways, lungs, kidneys). Dentists, orthodontists, dental-lab technicians dealing with infected removable orthodontic appliances (R.O.A.) have also a high risk through possible cross-contamination [9].

The photo-activated disinfection therapy demonstrated to be an efficient adjunctive method in periodontology and cariology $[10,11]$.

\section{Experimental part}

The aim of this study was to research the possibility of removing the microbial biofilm and disinfecting retainers using the photodynamic effect of toluidine blue 0 in comparison to two products available on the market. For this study the cold-cure acrylic Palapress ${ }^{\circledR}$ vario system (Heraeus-Kulzer GmbH, Hanau, Germany) was used.

The Palapress ${ }^{\circledR}$ vario is a pourable, cold-curing powder and liquid denture base material. The mixing ratio that we used was: $10 \mathrm{~g}$ of methylmethacrylate copolymer powder to $7 \mathrm{~mL}$ of acrylic liquid.

Starting from a single wax model we made a lot of acrylic plates (cold-cure acrylic Palapress ${ }^{\circledR}$ vario), each having a central well for the microbial biofilm experiments. Before the experiment, all this chips were kept for one hour in 3\% hydrogen peroxide solution, followed by one hour UV treatment for sterilization.

\footnotetext{
*email: balan.gheo@yahoo.com; laura_maria_g06@yahoo.com
} 
The microbial biofilm experiments were carried out using a strain of Streptococcus pyogenes ATCC 19615. The strain was kept at $-50^{\circ} \mathrm{C}$ in $\mathrm{BHI}$ (brain heart infusion) broth with glycerol and before each experiment was cultured on $\mathrm{BHI}$ agar $24 \mathrm{~h}$ at $37^{\circ} \mathrm{C}$. From the $\mathrm{BHI}$ agar plates the strain was cultured in Todd Hewitt (TH) broth for $24 \mathrm{~h}$ at $37^{\circ} \mathrm{C}$. The culture in broth was diluted 1000x in fresh TH broth and $150 \mu \mathrm{L}$ were placed on the surface of plastic chips and incubated at $37^{\circ} \mathrm{C}$ for $72 \mathrm{~h}$ in $100 \%$ relative humidity conditions. Each $24 \mathrm{~h}$ the culture media was removed, the chips were rinsed with distilled water and $150 \mu \mathrm{L}$ of fresh TH broth was added on each chip surface.

After the $72 \mathrm{~h}$ incubation period, the chips were rinsed with distilled water and divided in four groups: control (untreated), Corega (Corega Denture Cleanser Tablets GlaxoSmithKline), Brite (Brite ${ }^{\circledR}$ Cleaning Tablets DENTSPLY International Raintree Essix, FL, USA) and Toluidine blue Retainer (Fotosan System - CMS Dental, Copenhagen, Denmark).

Chips from the control group were placed in sterile saline solution, sonicated for 2 minutes at $40 \mathrm{kHz}$ to remove all attached bacteria, followed by serial dilutions and cultured on plate count agar and incubated for $24-48 \mathrm{~h}$ at $37^{\circ} \mathrm{C}$.

The Corega group was treated using Corega Denture Cleanser Tablets according to manufacturer instructions. A tablet was dissolved in $250 \mathrm{~mL}$ warm distilled water $\left(45^{\circ} \mathrm{C}\right)$, the chips were immersed in solution, kept for 3 minutes, rinsed, placed in sterile saline solution, sonicated followed by serial dilutions and cultured on plate count agar.

The Brite group was treated using Retainer Brite cleaning tablets according to manufacturer instructions. Briefly, one tabletwas dissolved in $250 \mathrm{~mL}$ warm distilled water $\left(45^{\circ} \mathrm{C}\right)$. The chips were placed into the solution, kept for 15 minutes, rinsed and then the same procedure as for the toluidine group was performed to quantify the effect of the procedure.

The toluidine blue group was treated using FotoSan agent with medium viscosity (toluidine blue $0-$ TBO, $0.1 \mathrm{mg} /$ $\mathrm{mL}$ ) and light treated with FotoSan $₫ 630$ (red light emitting device) for one minute. After light treatment, the chips were rinsed with saline solution $(0.9 \% \mathrm{NaCl})$, placed in sterile saline solution, sonicated for $2 \mathrm{~min}$ to remove all the attached bacteria, followed by serial dilutions and cultured on plate count agar in order to assess the effect of toluidine blue 0 .
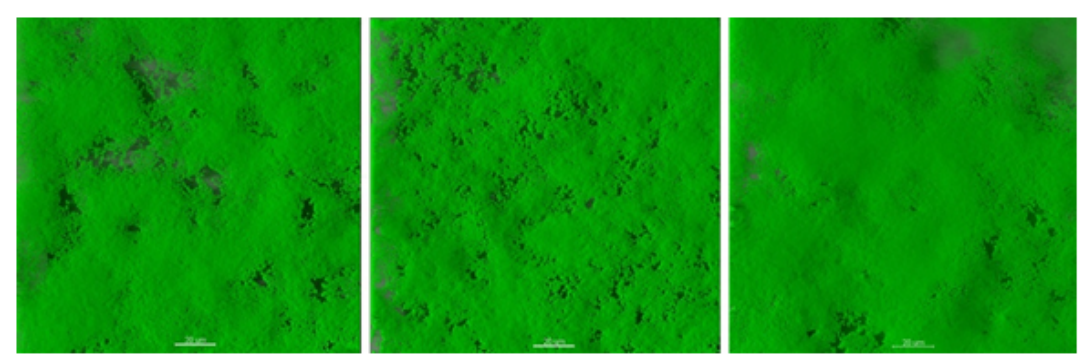

Fig. 1. Aspects of the Streptococcus pyogenes biofilm on Palapress ${ }^{\circledR}$ vario system

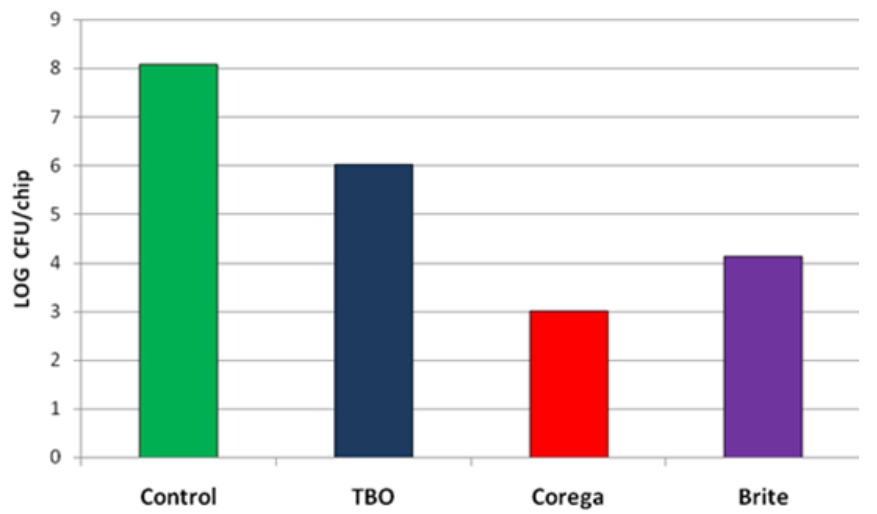

http://www.revmaterialeplastice.ro
The microbial biofilm formed on the cold-cure acrylic Palapress ${ }^{\circledR}$ vario system (Heraeus-Kulzer $\mathrm{GmbH}$, Hanau, Germany) was analyzed using a confocal laser scanning microscope (CLSM) model Leica DM2500. A 63x objective was used both in fluorescence and CLSM observations. Chips were stained using acridine orange $(A O)$ in acetate buffer solution (Sigma) for 2 min at room temperature, rinsed in pure water, air dried at room temperature and examined. The $488 \mathrm{~nm}$ laser was used for Z-stacks at a $400 \mathrm{~Hz}$ frequency and $30 \%$ power. The emission of the $\mathrm{AO}$ dye was captured between $520-550 \mathrm{~nm}$. The tridimensional images were analyzed using specific computer software COMSTAT 2.

\section{Results and discussions}

The confocal laser scanning microscope (CLSM) images showed that the Streptococcus pyogenes biofilm formed on all the chips of cold-cure acrylic Palapress ${ }^{\circledR}$ vario system (fig. 1).

The analysis of the biofilms destruction using COMSTAT 2 software showed an important reduction compared with the control group. All the 3 investigated materials had a disinfectant effect. Compared with the control group the Toluidine group showed a mean reduction of the colonyforming units (CFU) of $25 \%$, the Brite group a reduction of $50 \%$ and the Corega group an important decrease of $62.5 \%$

In the last years, the need for orthodontic treatments has increased. Very few studies have investigated the attitudes of dentist towards oral prevention measures. Children who are in the treatment of removable orthodontic appliances (ROA) have a higher risk for proximal caries, gingivitis, and halitosis as compared to children without ROA. The children's characteristics treated with orthodontic appliances are important and therefore, the dentist recommendation should present alternates to reduce microbiota and prevent other oral diseases [12].

The effect of exposure of disinfection methods on the properties of denture base materials is of prime importance. The most significant decrease in the surface hardness of heat cure acrylic resins was with Corega denture cleanser tablets when compared to the specimens at baseline (dry) and control group. This was followed by Fixodent denture cleanser tablets [13].

Orthodontic appliances must be disinfected not only while wearing them but also before the first application. (fig.2). 
It could be concluded that $85 \%$ of appliances made from acrylic resin presented infection post-manufacture in specialized laboratory cases. Also, disinfection with $2 \%$ chlorhexidine, the highest concentration examined in this study, had a statistically significant efficacy, disinfecting appliances in $91.3 \%$ of cases [14].

\section{Conclusions}

The results showed that all the three investigated methods had a disinfectant effect. Corega Denture Cleanser Tablets reduced most of the biofilm formed on the plastic substrate. Further research is needed to see the effects of exposure of the cold-cure acrylic Palapress ${ }^{\circledR}$ vario system (Heraeus-Kulzer GmbH, Hanau, Germany) to the different methods of disinfection.

Acknowledgement: This paper was supported by the project Competitia interna PIII-C2-PCFI-2015/2016, acronim DENTALOCT, title: "Fundamentari inovative si aplicative ale tomografiei optice coerente in medicina dentara. Validari experimentale alternative" and by the Sectorial Operational Programme Human Resources Development (SOPHRD) financed by the European Social Fund and the Romanian Government under the contract number POSDRU 141531.

\section{References}

1.ARDELEAN, L., BORTUN, C., MOTOC, M., RUSU, L., Mat. Plast., 47, no.4, 2010, p. 433.

2.ROSA, L.P., DA SILVA, F.C., NADER, S.A., MEIRA, G.A., VIANA, M.S., Photodiag. and Photodynamic Therapy, 12, 2015, p. 276.
3.LESSA, F.C.R., OKI, C., YOKOITO, I., FARIA, G., MATSUMOTO, M., FILHO, P.N., Am J Orthod Dentofacial Orthop, 131, 2007, p. E11705.E17. 4.AMITHA, H., MUNSHI, A.K., J. Clin. Pediatr. Dent., 20, 1995, p. 23.

5.ALEV, A., GULCIN, K., EMAD, H., ADARLEEN, A., Sterilization and Disinfection in Orthodontics, Principles in Contemporary Orthodontics, Dr. Silvano Naretto (Ed.), ISBN: 978-953-307-687-4, InTech Publ., 2011.

6.EARAR, K., BICA, C., CERGHIZAN, D., ILIE, M., Mat. Plast., 53, no. 3, 2016, p. 512.

7.EARAR, K., CERGHIZAN, D., SANDU, A.V., MATEI, M.N., LEATA, R., SANDU, I.G., BEJ INARIU, C., COMAN, M., Mat. Plast., 52, no.4, 2015, p. 487.

8.EARAR, K., MATEI, M.N., SANDU, A.V., HRISTIAN, L., BEJINARIU, C., SANDU, I.G., Mat. Plast., 52, no.1, 2015, p. 98.

9.OGODESCU, A.S., MORVAY, A.A., LUCA, M.M., OGODESCU, A.E., ZETU, I., Mat. Plast., 51, no.4, 2014, p. 424.

10.SOLOMON, S., URSARESCU, I., MARTU, A., LUCHIAN, I., FORNA, D.A., MARTU, S., FORNA, N.C., Rev. Chim.(Bucharest), 66, no. 8, 2015, p. 1166.

11.OGODESCU, A.S., MORVAY, A.A., OGODESCU, A.E., SINESCU, C., ROSU, S., BARLEAN, L.M., Rev. Chim.(Bucharest), 67, no. 11, 2016, p. 2360.

12.LAMAS, R.R.S., SALAS, M.M.S., CENCI, T.P., CORREA, M.B.L., RAFAEL, G., Brazilian J. of Oral Science, 15, No.1, 2016, p. 21.

13.AMIN, F., AKRAM, S., SHAIKH, A.A., J. Pak Dent Assoc, 24, No. 2, 2015, p. 87.

14.MOREIRA, L.V.G. et al., Afr. J. Microbiol. Res., 10, No. 27, 2016, p. 1051.

$\overline{\text { Manuscript received: } 15.12 .2016}$ 